\title{
Copyright Commercialization of Songs Uploaded in TikTok Application Without the Creator's Permission
}

\author{
Fakhira Meshara Salsabila, Ranti Fauza Mayana, Laina Rafianti \\ Fakultas Hukum Universitas Padjadjaran, Bandung, Indonesia \\ Email: fakhira17001@mail.unpad.ac.id
}

\begin{abstract}
TikTok has now become an application that is widely used by all people and that it has become a trend. The application has a General Terms of Services which is the basis for using Tiktok. In the practice of uploading songs by users without realizing it, gives a juridical implication because users do not fully understand the provisions contained in the Terms of Services. Appropriately, before the user takes and modifies the work of the song which is then used for commercial use, the user already has a license or permission from the author. The problems studied are the legal consequences of uploading songs in this TikTok application which are commercialized without the permission of the Creator by the related users, as well as to see the legal efforts that can be taken by the Creator on songs that are commercialized without the permission of the Creator in this application. The research method used is juridical normative, namely an approach method that uses laws and legal principles as a means of solving the problems at hand. The results of the research conclude that currently, the violation of Copyright has changed from criminalization to remuneration, where the legal consequence of the Copyright infringement is non-compensation to the Creator due to commercial use of songs. Regarding the protection efforts, it can be done in several ways, namely recording, administrative legal remedies and supervision. In terms of fulfilling the rights of the Creator, legal remedies can be taken, namely preventive and repressive measures consisting of civil and criminal remedies. In addition, it can also be resolved by alternative dispute resolution and arbitration.
\end{abstract}

Keywords: Commercialization, copyright, TikTok application

\section{INTRODUCTION}

Nowadays science and technology are getting more advanced, this makes it easier for humans to exchange information, one of which is the internet. With its advantages, the internet has penetrated almost all sectors of human life, from health, industry, education, trade, to the entertainment sector (Saidin, 2004, p. 519). The internet, which is used as a medium for information technology in which there are digital works, means that these digital works can be continuously reproduced and distributed to millions of people in a very short time, just by pressing a few computer buttons (Yusran Isnaini, 2009, p. 1).

Currently internet users are increasing from year to year, including in Indonesia. Technological developments in the world today will consciously or not, influence developments in the realm of intellectual property. The power, feeling and intention that are manifested in the form of valuable intellectual works are the result of human intellectual abilities, especially with the inherent economic benefits so that the concept of wealth will foster intellectual works (Margono, 2001, p. 4).

One of the results of human intellectuality is an application or program. New applications and / or programs in both computers and / or smartphones began to appear. 
Smartphones are increasingly active in making programs that are popular with the wider community. The application made is used in smart phones known as social media.

TikTok is a social media application that is being favored by the wider community from all walks of life from children to adults. This application, which has been around since 2016, has become trending since the end of 2019 and TikTok users are increasing until now. This short video-based application can be enjoyed in a duration of 15 seconds or 60 seconds. In the short video, the content creator is given the widest possible creativity in uploading videos accompanied by music, filters and several other features.

Content uploaded in an application cannot be separated from the elements of intellectual property owned by every human being. The result of human intellectual thought which requires the sacrifice of time, effort and expense is called Intellectual Property. As for the benefits of intellectual property for creators, it is the protection of the results of their intellectual power in creating works (Pawitram, 2017, p. 2).

Regulations regarding Intellectual Property are internationally regulated by the World Trade Organization (WTO) in the Agreement Establishing the WTO which includes the Agreement on Trade Related Aspects of Intellectual Property Rights, hereinafter referred to as the TRIPs Agreement. The TRIPs Agreement is a regulation regarding the protection of IP in particular including the Copyright in it which is contained in Annex 1c of the Marrakesh Agreement Establishing the World Trade Organization. Indonesia is a member country in the WTO Agreement Establishing which ratified it through Law Number 7 of 1994 concerning Ratification of the WTO Agreement. As a member country, legal harmonization is carried out in making regulations with the TRIPs Agreement to comply with standards and there is no contradiction between national legal regulations and the TRIPs Agreement (Dharmawan, 2017, p.17).

Intellectual Property (IP) is divided into two, namely Individual and Communal. Individual IP includes copyright including rights related to copyrights, trademarks, geographic indications, patents, industrial designs, integrated circuit layout designs, trade secrets and protection of plant varieties. One of the regulations governing intellectual property in Indonesia is Law Number 28 of 2014 concerning Copyright (Sudaryat, 2019, p. 12).

Copyright is an exclusive right owned by an Author that arises automatically based on a declarative principle. This right arises after a creation is manifested in a tangible form. In its protection, there are types of works protected by copyright contained in Article 40 paragraph (1) of the UUHC, one of which is a song and / or music with or without text (Ardika, 2019, p. 4). There are moral rights and economic rights of creators attached to a work, in this case the song or music that is protected by UUHC.

In connection with the TikTok application which is becoming a trend today, of course there are songs or music in the application which, if associated with copyright, have Moral and Economic Rights which are protected by UUHC. Moral rights are inherent rights and cannot be transferred until the creator dies, whereas economic rights are the right to benefit from intellectual property rights, can be said to be economic rights because intellectual property rights are an object that can be valued in money (Supramono, 2010, p. 45). The thing related to economic rights is royalties. This is important in the administration of Copyright which often escapes the attention of Copyright users.

The development of the digital world today has a variety of impacts, both positive and negative. The ease of getting access and uploading, in this case songs on various social media applications, is one of the positive impacts, on the other hand there is also a negative impact. The negative impact that arises is that the occurrence of Copyright infringement on songs 
uploaded in the TikTok application can be in the form of violations of Moral Rights, Economic Rights including royalties in it.

TikTok in its application already has terms of service that explain the content uploaded in the application which explains that when the user submits the artificial content into the TikTok application, the user states and agrees that the content uploaded into the application belongs to the user. In creating this content, the user has been authorized by the Creator from each part of the user-generated content (TikTok, 2020).

From these provisions, it can be interpreted that every content uploaded in the application must have permission from the Creator, but in reality, the application user does not give permission to the Creator in uploading content into the TikTok application. In Article 5 paragraph (1) letter e of the UUHC, it is stated that a Creator or a Copyright Holder can "defend his rights if there is a distortion, mutilation, or modification of the Work, or things that can harm the reputation or self-respect of the Creator. a work cannot be distorted, mutilated, or modified. In this application the song is used as music that accompanies a movement or dance because it is only uploaded in a duration of 15 seconds or 60 seconds, so the song is not enjoyed in full. In addition to reducing the duration of time with the use of sound effects and changing the tempo of the song, it has also changed the originality of a creation, especially if it is done without the author's permission. This can be said to be a form of mutilation and modification of a work that has the potential to become a form of violation of the law.

The use of this distorted, mutilated, and modified song attracts users to use this song in creating content on the TikTok application. As a result of the massive use of the song, the song is systematically recommended by TikTok for its users. After entering the song recommendation column, it is widely used so that an algorithm is created in the TikTok application that displays content with the content of the song continuously. This makes the content get public attention which results in the content of the content being conveyed well. This condition is what attracts users to take advantage of the song for profit.

One of the benefits that can be achieved by users is opening endorsement services in the form of video content. Endorsement is a form of mutually beneficial cooperation between the two parties. Currently, social media endorsements are being carried out by artists or celebrities who collaborate with online shops. This meaning or celebration has many fans and followers who are useful for increasing sales for online shops and certain products and services (Hartini, 2016, pp. 43-50). TikTok users will open endorsement services by determining a certain standard rate for creating content.

The above case was discovered by researchers in the song Making A Lover from SS501 which is used by many TikTok users in their endorsement services. Items that are promoted by users are of various types, but this does not hinder the spread of the content. This proves that using the song optimally can improve the quality of content distribution that benefits TikTok users. This has the potential to cause legal problems, especially regarding the economic rights possessed by the composer of the song. Based on the background above, several problems will be described which will be the reference and direction of the focus of this research. The problems are as follows:

1. The legal consequences of uploading songs in the TikTok application that are commercialized without the author's permission by the user are related to the Creator's royalties.

2. Legal remedies that can be taken by the Creator on commercialized songs without the author's permission in the TikTok application. 


\section{METHODS}

This research is descriptive analytical which is intended to provide a detailed, systematic, and comprehensive description of statutory regulations and legal theories, as well as using the normative juridical methods. The normative juridical method is an approach method in solving the problems faced using existing legal principles. This method begins by analyzing the articles in the Copyright Law which regulate the commercialization of Copyright, violations of Moral Rights and Creator's Economic Rights. This legal research is carried out by conducting research using library materials or secondary data as the basic material for research, namely by tracing the problems under study based on regulations and related literatures.

\section{RESULT AND DISCUSSION}

\section{The legal consequences of uploading songs in the TikTok application that are commercialized without the author's permission by the user are related to the Creator's royalties.}

When using the TikTok application, uploading songs is something users always do. The TikTok application provides a large selection of songs that can be used by users to create content. Song uploads in the TikTok application only last for about 15 (fifteen) to 60 (sixty) seconds.

In general, a song created by a majority creator has a duration of more than 60 (sixty) seconds or 1 (one) minute so that the songs that are enjoyed in the TikTok application are not complete. The song is cut from the actual song or can be said to be a mutilation. Mutilating a work, in this case a song, is a form of violation of the Moral Rights of the Creator as regulated in Article 5 paragraph (1) letter e of the UUHC, that in the event of distortion, mutilation and modification of the work, or there are things that can harm self-respect or reputation of the Creator, the Creator as the owner of the work has the right to defend his / her rights. The song is used by users to promote or endorse a product in the TikTok application. Activities to promote or endorse are activities that generate profits or can be said to be commercialization.

The practice of uploading songs in the TikTok application that is used for commercialization is now easy to find. One of them is the use of a song entitled Making a Lover which was popularized by the South Korean music group SS501. For example, the use of the song Making a Lover from SS501 is used by the TikTok @ deasilistiani account, which has 1.5 million followers, in this case the account uses the song Making a Lover to endorse a skin care product, namely a face mask from an online shop on Instagram. @ ohmyskin.official, the content received 1.7 million viewers, 353,400 thousand likes, 5601 comments, and 4892 shares. User uses the song in endorsing a product without the permission of the Creator or Copyright Holder.

Currently, permissions are not always granted directly by the Creator. In using the song, users can get permission from the Collective Management Institute based on a license made by the Creator or Copyright Holder. TikTok is an application that is on the internet network. Royalty collection conventionally does not necessarily apply to copyrighted works that are on the internet. Until now, there has been no clear regulation regarding the collection of royalties on Copyright in the digital world. With the rapid development of technology, the distribution of Copyright is accelerating to be accessed by the wider community.

With regard to this regulation, in December 2020 LMKN in collaboration with the Ministry of Education and Culture held a Focus Group Discussion (FGD) which discussed legal protection for users of music through digital platforms. The FDG also discussed the 
importance of regulations governing royalty collection in digital. In facing the industrial era 4.0 in the field of Copyright, especially mechanical rights to music or songs, the Directorate General of KI pays serious attention through the Directorate of Copyright and Industrial Design.

A person who gives birth to a creation for the first time is called a Creator, so that he is the first person to have rights as a Creator. Leigen argues that a creator is the subject of copyright, so that someone who is the object of copyright law is the creator of a work (Damian, 2019, p. 130). Creators have Moral Rights and Economic Rights over their works.

In a work, there are rights that only the Creator can exercise these rights and cannot be separated from the Creator, namely, Moral Rights. In general, Moral Rights are the rights so that a work cannot be changed or tampered with without the consent of the Creator, as well as the right to be recognized as the Creator of the work (Hutagalung, 2012, p 30). Moral rights are things that are eternally attached to a Creator which is useful for keeping or not including the Creator's name in the event that the work is used for the public. The right to be able to use his alias or pseudonym. The right to change the work in accordance with the appropriateness of society. The right to change the title and sub-title of the work. And the Creator has the right to defend his rights in the event of distortion, mutilation, and modification of the work, or things that may harm his / her honor or reputation.

The right to benefit from a work that is owned by an author is an economic right. The exploitation rights of a work can also be equated with economic rights. Exploitation rights give rights to the creator or copyright holder within a certain period of time to exploit the economic benefits of his work (Maulana, 1996, p 144).

The creator has given satisfaction or something meaningful or added value to society. Therefore, it is very natural for people who benefit from copyright works to give rewards in the form of rewards to the creators or copyright holders (Nainggolan, 2016, p. 62). Based on Article 9 paragraph (1) of the UUHC, it is explained that the Creator or Copyright Holder has several Economic Rights, including the right to publish, duplicate, translate, adapt, arrange, or transform, distribute, show, announce, communicate, and rent Works.

In Economic Rights, it is closely related to royalties. a reward for the use of Economic Rights of Works received by the Author or referred to as royalties. Royalty is a certain value paid to the owner of intellectual property for the economic enjoyment of an intellectual property, the amount of which is agreed upon by the parties, for a certain period of time. As long as the copyright work is commercialized, there is an obligation for the publisher to pay royalties to the creator or copyright holder.

In principle, all copyrights will have an impact on economic rights obligations when used for commercial purposes. Based on Article 1 point 24 of the UUHC, it is explained that the use of Works and / or Related Rights products carried out with the aim of obtaining an economic benefit from various sources or paid for can be said as Commercial Use (Ramli, 2018, p. 9).

The benefits obtained by the user in endorsing a product are not sent directly to the Creator, when the Creator actually has the Economic Right to get royalties from the user for this benefit. The creator is entitled to get royalties because the song used in endorsing a product is a work that is owned by the creator. As a Creator, obtaining an economic advantage over creation is his right. The right to get these benefits for many reasons, one of which is in producing the copyrighted work the Creator has spent energy, thought, time and money, as a form of justice, logically the Creator has the right to obtain and prioritize his rights (Rotinsulu, 2016, p. 18). 
Based on the Copyright Law, all parties who have used copyrighted works, namely songs belonging to other people for commercial purposes, then that person has an obligation to ask for permission from the composer of the song and must pay royalties for the use of the song. By using songs to endorse without the author's permission, this is a form of violation of Economic Rights. Violation of an Author's Economic Rights which takes without permission from the Author or Copyright Holder which is then used for commercial purposes and also without paying royalties or compensation that must be received by the Author is a form of criminal act.

If you see the use of songs uploaded by users in the TikTok application for endorsement content, it is a violation of the Creator's Economic Rights. These actions can be said to be a form of violation of the Creator's Economic Rights due to commercial use without the author's permission. By uploading the song into the application and using the song without the author's permission to generate profit, this violates Article 9 paragraph (1) of the UUHC, one of which is the arrangement of the Work.

A song with a sound added as a back sound can indirectly be said to be a form of song arrangement. The sound is added to a new "layer" which becomes an integral part of the song. In Article 9 paragraph (2) of the UUHC, it is explained that in exercising Economic Rights everyone must obtain permission from the Creator or Copyright Holder, which means that the use of songs uploaded to the TikTok application for endorsement activities must be with the permission of the songwriter. In the next paragraph it is stated that everyone is prohibited from using the Work commercially if without the permission of the Creator or Copyright Holder it means that TikTok application users are not allowed to use songs commercially without the author's permission.

Basically, the use of a copyright work cannot be considered a violation of copyright as regulated in Articles 43 and 44 of the UUHC. In Article 43 letter d of the UUHC, it is stated that Copyright content created and disseminated on information and communication technology media does not constitute a violation if it is not commercial and / or profitable. In the event that the Creator states that he does not object to the content created and distributed, it is also not a violation. Such use is a fair use or what is known as the fair use doctrine so that it does not violate the economic rights of the creator.

If it is proven that there is a violation of the Creator's Economic Rights, then there are legal consequences for the violation and the offender must be punished, both civil and criminal. These violations have been regulated in Article 113 of the UUHC which explains that criminal sanctions for commercial violations of Economic Rights are punishable by a maximum of 1 (one) year in prison and / or a maximum fine of IDR 100,000,000 (one hundred million rupiah). Violation of Economic Rights, namely adapting, arranging, or transforming Works, translation of Works, performing works and communication of Works carried out without rights and / or without permission of the Creator or Copyright Holder who are used commercially, will be punished with a maximum imprisonment of 3 (three) years and / or a maximum fine of IDR 500,000,000 (five hundred million rupiah). Meanwhile, criminal sanctions against economic rights, namely the publication of works, duplication of works, distribution of works or copies thereof, performances of works, and announcements of works are subject to a maximum imprisonment of 4 (four) years and / or a maximum fine of Rp. 1,000,000,000 (one billion rupiah). Finally, every person who violates Economic Rights, namely publishing a work, duplicating a work, distributing a work or copy thereof, performing a work, and announcing a work made in the form of piracy, will be subject to a maximum imprisonment of 10 (ten) years and / or a maximum fine of Rp. 4,000,000,000 (four billion rupiah). The majority of sanctions that are regulated are criminal sanctions. Violations that occur in the TikTok application are 
violations in an electronic system that uses the internet network. In the case of copyright infringement through an electronic system, there is a form of administrative sanction regulated in Article 56 of the UUHC. In this article, it is explained that if the reported Copyright infringement has been verified, the Minister can do things, namely closing the content, and / or the access rights of users who have violated Copyright in an electronic system can also be closed and electronic system services cannot be accessed.

Copyright infringement imposed with such criminal sanctions can be said to be a form of criminalization. Currently, criminalization has been abandoned and has shifted to remuneration. In the era of remuneration, it is closely related to administrative sanctions. As it means that remuneration is giving gifts, giving this gift in Copyright can be in the form of credit or compensation to the Creator. Compensation for creators is a form of administrative sanction given to users, in this case TikTok users. Of course, the amount of compensation has been agreed upon by the Creator and User.

In the TikTok application, there is no clear mechanism for making credits for the songs used. Crediting is done by the user when the user uses a dance move on the content. The credit is written in the video caption which is usually a tag to the Creator of the movement. By using songs in the content uploaded on the TikTok application, it does not deny that the song is becoming popular and increasing so that it is more widely known by the wider community. This is an advantage for the Creator regardless of the use of the song has not obtained a license.

\section{Legal Remedies That Can Be Taken by the Creator Against the Protection of Commercialized Songs Without the Author's Permission in the TikTok Application}

The law has recognized that copyright exists automatically since the work was completed. It can be interpreted that after the creation is finished, it is manifested in a tangible form according to the wishes of the Creator (Soelistyo, 2011, p. 12). Therefore, legal protection will arise when the work is materialized. Copyright does not require that the work be registered, but if the registration is done this will be much better, because by registering a Copyright there will be formal evidence as ownership of the Copyright (Dewi, 2017, p.15).

The copyright of the song is automatically created, not when the song is finished recording or displayed, but the copyright of the song is automatically there when the song can be heard and is proven by the presence of music notation and / or without lyrics. Violations that occur in Copyright are divided into 3 (three) things, namely direct violations, indirect violations, and violations on the basis of authority (Janed, 2014, p. 125).

Currently, the provision of copyright protection in internet media is still having difficulties because there has not been found a truly safe way from copyright infringement. Protection of copyright songs that are on the internet can be done by means of legal protection, namely by enforcing regulations through state administrative law with recording and supervision, criminal law, civil law, and alternative solutions.

In terms of state administrative law, what can be used as a benchmark for legal protection is the registration of rights to prove the creator has rights to the work of his creation. According to the elucidation of Article 64 Paragraph (2) of the UUHC, a Creator, Copyright Holder or Related Rights Owner is not a necessity in recording a work. Recording is not a determining factor for the protection of a work because since the work is manifested, protection for the work has begun. This means that a work, whether it is recorded or not, will still be protected (Kusno, 2016, p. 492).

The recording is carried out by the Ministry of Law and Human Rights of the Republic of Indonesia. To get the work recorded, the applicant can submit an application through three alternative ways, namely through the Directorate General of Intellectual Property (Ditjen KI), 
through the Regional Office of the Ministry of Law and Human Rights of the Republic of Indonesia, or through a registered KI Consultant Legal Counsel (Yustia, 2015, p. 20).

Listing cannot deny the occurrence of a Copyright infringement. Efforts that can be made in reducing violations of copyright are licensing. Licensing relates to a license for commercial use. The profit that results from commercial use, there are rights owned by the Creator or Copyright Holder. Users are obliged to provide compensation for the use of songs to the creators or copyright holders, known as royalties. In practice, what has become a problem is that users don't have a license for the song.

The license can be granted to the Collective Management Institute or LMK. With the various types of works, this has resulted in many LMKs that focus on collecting royalties for each type of work. In the type of music and song creation, there are several LMKs that have the right to collect royalties. The two most well-known LMKs are the Karya Cipta Indonesia Foundation (YKCI) and Wahana Musik Indonesia (WAMI). LMK has a role in collecting and distributing royalties to creators or copyright holders from the use of music and songs.

LMK is an institution that has the authority to manage Economic Rights by collecting and distributing royalties after being authorized by the Author, Copyright Holder, and / or Related Rights owner. In this case, LMK carries out its role in providing legal protection for music creators and related parties. To that end, it encourages LMK to cooperate with record producers. The current provisions, namely Government Regulation Number 56 of 2021 concerning Management of Royalties on Copyright for Songs and / or Music, do not yet specifically regulate digital copyright works, but they still regulate the collection and distribution of royalties conventionally. In the future, arrangements are needed for digital copyrighted works to be able to manage royalties from digital music platforms, which have not paid royalties so far.

In terms of supervision, the Copyright Law states that the Minister in this case the Minister of Communication and Information Technology has a supervisory role in the operation of Copyright. Regarding the prevention of violations of Copyright and Related Rights that are carried out by means of information technology is regulated in Article 54 of the UUHC. The article explains that the government can prevent the prevention of the content of violations of Copyright and Related Rights which are made and disseminated. The government can also cooperate and coordinate with domestic and foreign parties in preventing the creation and dissemination of copyright and related rights infringement content. The Government also conducts supervision at the venue if there is an act of recording using any media of Works and Related Rights products.

If the use of the song used by the user is not desired by the Creator or Copyright Holder, there is not yet a mechanism for the Creator or Copyright Holder to delete or withdraw the song he created from the TikTok application directly. One of the steps that a creator or copyright holder can take if it is felt that TikTok does not have the right to duplicate its work is to sue in court. This has been done by PT Digital Chain Maya, which sued TikTok Pte Ltd and Bytedance. TikTok is deemed to have violated the Related Rights of the copyright of PT Digital Chain Maya with the songs on the master sound / master recording sung by Virgoun.

In overcoming a Copyright infringement that occurs, especially by changing the tone, tempo and the removal of part of the contents of a song uploaded and commercialized on the TikTok application, there are legal remedies that can be taken by the Creator. Protection in terms of civil law and criminal law, there are two measures, namely preventive measures and repressive measures.

In the event of a violation of a copyright work, the Creator can take legal remedies, namely preventive legal remedies in an effort to prevent or avoid infringing acts of a 
copyrighted work. Preventive efforts are made in order to reduce the use of songs that have partially removed the contents of the song or have been modified which are used for commercialization by users of the TikTok application on the TikTok application service. The existence of preventive legal protection encourages the Government to be careful in making decisions. The purpose of these preventive measures is to prevent disputes in court.

The party that plays the most important role in seeking protection of Copyright which is a violation is the Creator because he is the owner of the Copyright itself. Registering a work is a preventive action that can be taken by an author or copyright holder to obtain legal protection and legal certainty regarding the rights to his creation, if a dispute occurs in the future, the registration of the work can be used as evidence in court. Understanding of Copyright, especially Law Number 28 of 2014 is important for Creators. By understanding the Law, the Creator will understand his rights as the Creator. If there is a commercial use of a work and the creator feels aggrieved by the use, then in essence the creator knows what to do to defend his copyright.

If a violation of the copyright work has occurred, there are legal remedies that can be taken by the Creator, namely repressive measures. Repressive efforts are an effort to overcome the occurrence of acts of using songs that have partially removed the contents of the song or have been modified which are used for commercialization by users of the TikTok application on the TikTok application service.

In addition, repressive measures are also steps that can be taken by creators or copyright holders in that their works are used by other parties without the author's permission. There are changes to the copyright work and the removal of part of the work or commercial use, so that the creator or copyright holder of the song is violated both moral rights and economic rights. The purpose of repressive measures in legal protection, namely to resolve disputes, the handling of legal protection by the General Courts in Indonesia, which is included in this category of legal protection.

In overcoming violations of Copyright, repressive measures that can be made through legal means, namely by taking the path of civil law and / or criminal law. Civil law channels can file a lawsuit at the Commercial Court. Such a lawsuit can be filed by the Creator, Copyright Holder, and Related Rights Owner in accordance with the lawsuit procedure. A lawsuit is submitted to the competent Chair of the Commercial Court so that the claim can be recorded by the clerk of the Commercial Court on the date the lawsuit is filed.

If the violation results in a loss, the Creator, Copyright Holder, or Related Rights Owner can file a lawsuit and are entitled to obtain compensation. The article that regulates compensation is contained in Article 1365 of the KUHper, which states that every act violating the law which causes harm to other parties, then the person who commits the violation is obliged to provide compensation. The period of giving the compensation to the Creator, Copyright Holder, or Related Rights Owner is paid a maximum of six months after the inkracht court decision.

In Article 99 paragraph (3) of the UUHC, it is explained that if the Creator, Copyright Holder, or Related Rights Owner feels a loss as a result of the copyright infringement they have, they can request a provincial decision or an interlocutory decision to the Commercial Court in terms of requesting confiscation of Works that are carried out with an announcement, and / or duplication tools used to produce a work resulting from infringement of Copyright and Related Rights products. Creators, Copyright Holders, or Related Rights Owners can request cessation of the Announcement, Distribution, Communication, and / or Reproduction of Works which are the result of infringement of Copyright and Related Rights products. 
In the effort to enforce the law and to recover the copyright infringement that is produced exactly the same as the original work, it can be done in several ways. As for the temporary stipulation, civil recovery efforts, criminal sanctions, preventive facilities at the border by customs, and preventive means related to digital management technology and information facilities (Soemartono, 2006, p. 11).

The criminal law route is one way of legal action that can be taken in resolving cases of violations of music or song creations. In criminal efforts, there are 2 (two) legal remedies, namely ordinary legal remedies consisting of appeals and cassations as well as extraordinary legal remedies consisting of Review and Legal Interests in terms of injustice in court decisions felt by one of the parties in the case.

In addition to civil and criminal legal remedies which are court dispute settlement, there are other dispute resolutions, namely alternative dispute resolution and arbitration. This is regulated in Article 95 of the UUHC which explains that alternative dispute resolution, arbitration, or courts are ways that can be taken in resolving Copyright disputes. In resolving copyright disputes, the Commercial Court is a court that has the authority to resolve Copyright disputes other than the Commercial Court is not authorized. The article also explains that as long as the parties involved in the dispute are in the territory of the State of Indonesia and / or their existence is known to be obliged to settle through a mediation process before the criminal charges are made, if the violation is not committed, it is not piracy.

In the case of a Creation that occurs, namely a song uploaded by a user on the TikTok application, the song is modified in tone and sound and mutilated or partially cut from the part of the song which is then used for commercial activities, in this case endorsement without the author's permission. The act has caused a loss to both the Moral Rights or the Economic Rights of the Creator. In connection with this case, 2 (two) sanctions can be imposed, namely civil sanctions and criminal sanctions.

In resolving cases of copyright infringement, both criminal and civil legal remedies can be said to be quite Currently, the provision of copyright protection in internet media is still having difficulties because there has not been found a truly safe way from copyright infringement. Protection of copyright songs that are on the internet can be done by means of legal protection, namely by enforcing regulations through state administrative law with recording and supervision, criminal law, civil law, and alternative solutions.

In resolving cases of copyright infringement, both criminal and civil legal remedies can be said to be quite effective. In civil law efforts, the emphasis is only on the compensation process. Meanwhile, criminal prosecution results in a deterrent effect in the form of body imprisonment for the perpetrator of a crime or offense.

\section{CONCLUSION}

Based on the discussion, the following conclusions can be drawn. The act of uploading commercialized songs without the author's permission is a form of violation of Article 5 paragraph (1) letter e and Article 9 paragraph (1) of the UUHC. Every person who wants to use someone else's work, namely a song, must first ask the author of the song and must pay royalties if it is used for commercial purposes. The granting of a license can be done by way of a license through the Collective Management Institute. By using a song to endorse without the author's permission, it violates Economic Rights and Moral Rights. This is even more so if the use of the work does not pay royalties or profits which are the rights of the Author. If it is proven that there has been a violation of the Creator's Economic Rights, then there will be legal 
consequences for the violation committed and the offender can be punished, both civil and criminal.

In the event of a copyright violation, efforts that can be made before entering the court is by registering the Copyright and monitoring in terms of state administrative law. There are 2 (two) legal remedies that can be taken by the Creator, namely Preventive Efforts and Repressive Measures. Preventive Efforts are efforts to prevent violations of the law in this case by registering a work. Repressive measures are efforts to overcome if there is a violation of the law, namely by means of trial, namely civil and criminal attempts and there are other dispute resolution methods, namely alternative dispute resolution and arbitration.

\section{REFERENCES}

\section{Books}

Budi Maulana, Insan. (1996). 108 Tanya Jawab Paten, Merek, Dan Hak Cipta. Bandung: Citra Aditya Bakti.

Damian, Eddy. (2019). Hukum Hak Cipta. Bandung: PT Alumni.

Hutagalung, S.M. (2012). Hak Cipta Kedudukan dan Peranannya dalam Pembangunan. Jakarta: $\quad$ Sinar Grafika.

Isnaini, Yusran. (2009). Hak Cipta dan Tantangannya di Era Cyberspace. Bogor: Ghalia Indonesia.

Janed, Rahmi. (2014). Hukum Hak Cipta: Copyright's Law. Bandung: Citra Aditya Bakti. 2014.

Margono, Suyud. (2001). Komentar Atas Undang-undang Rahasia Dagang, Desain Industri, Desain Tata Letak Sirkuit Terpadu. Jakarta: CV Novindo Pustaka Mandiri.

Nainggolan, Bernard. (2016). Komentar Undang-Undang Hak Cipta. Bandung: PT. Alumni. Ramli, Ahmad M. (2018). Hak Cipta Disrupsi Digital Ekonomi Kreatif. Bandung: PT. Alumni. Saidin, OK, (2004). Aspek Hukum Hak Kekayaan Intelektual (Intellectual Property Rights). Jakarta: Rajawali Pers.

Soelistyo, Henry. (2011). Hak Cipta Tanpa Hak Moral. Jakarta: PT Raja Grafindo Persada.

Soemartono, Gatot. (2006). Arbitrase dan Mediasi di Indonesia. Jakarta: Gramedia Pustaka Utama.

Sudaryat (et.al). (2019). Hukum Kekayaan Intelektual Cakupan dan Prinsip Dasar. Bandung: CV. Global Sinergi Indonesia.

Supramono, Gatot. (2010). Hak Cipta dan Aspek-aspek Hukumnya. Jakarta: Rineka Cipta. Yustia, Tim Visi. (2015). Panduan Resmi Hak Cipta Dari Mendaftar, Melindungi, hingga Menyelesaikan Sengketa. Jakarta: Visimedia.

\section{Journals}

Ardika, Komang, dan Marwanto. (2019). Pemanfaatan Lagu Secara Komersial Pada Restoran Serta Keberadaan Pengunjung Yang Menyanyikan Lagu Secara Volunteer. Jurnal Ilmiah Ilmu Hukum Kertha Semaya, Vol. 7, No. 6.

Dharmawan, Ni Ketut Supasti. (2017). Protecting Traditional Balinese Weaving through Copyright Law : Is It Appropriate?. Jurnal Diponegoro Law Review, Vol. 2, No. 1.

Hartini, S. (2016). Efektifitas Endorsment Pada Media Sosial Instagram Pada Produk Skin Care. Bina Insani ICT Journal, Vol. 3, No. 1.

Kusno, Hasbi. (2016). Perlindungan Hukum Hak Cipta Terhadap Pencipta Lagu yang Diunduh Melalui Internet. Fiat Justisia Journal of Law, Vol. 10, No. 3. 
Pawitram (et.al). (2017). Pengaturan Lembaga Manajemen Kolektif Berkaitan Dengan Penarikan Royalti Berdasarkan Undang-Undang Nomor 28 Tahun 2014 Tentang Hak Cipta. Jurnal Ilmiah Ilmu Hukum Kertha Semaya, Vol. 5, No. 1.

Rotinsulu, Lucia Ursula. (2016). Penegakkan Hukum Atas Pelanggaran Hak Ekonomi Pencipta Lagu Menurut Undang-Undang Nomor 28 Tahun 2014. Lex Crimen, Vol. V, No. 3.

Satria, Mirah Dewi. (2017). Perlindungan Hukum Hak Cipta Terhadap Cover Version Lagu di Youtube. Jurnal Magister Hukum Udayana, Vol. 6, No. 4.

\section{Laws and Regulations}

Undang-Undang Nomor 28 Tahun 2014 tentang Hak Cipta

Webisite

Aplikasi TikTok, "Tentang Term of Services”, https://www.TikTok.com/legal/terms-ofuse?lang=id Accessed 12 September 2020. 